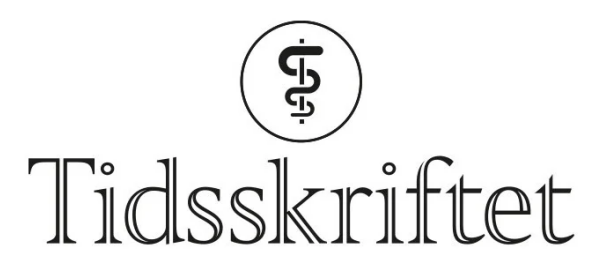

DEN NORSKE LEGEFORENING

\title{
Norge trenger flere barn
}

\author{
FRA REDAKTØREN
}

MARTINE ROSTADMO

martine.rostadmo@tidsskriftet.no

Martine Rostadmo er lege og publiseringsredaktør i Tidsskriftet.

\section{Halvparten av verdens flyktninger er barn.}

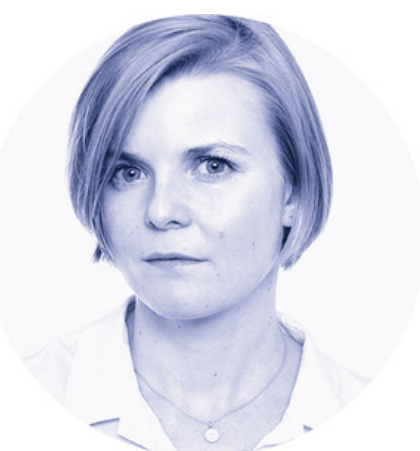

Foto: Sturlason

«Norge trenger flere barn», sa statsminister Erna Solberg i sin nyttårstale i 2018 (11). På Lesvos sover nyfødte på gata, og det er flere mennesker på flukt i verden i dag enn det var under annen verdenskrig. Nærmere 80 millioner mennesker er på flukt, det vil si $1 \%$ av verdens befolkning. Nesten 34 millioner har krysset minst én landegrense, mens nesten 46 millioner er fordrevet i sitt eget land som følge av konflikt eller katastrofe. 26 millioner har status som flyktning etter internasjonal rett. Halvparten av disse er barn (므). Til SørEuropa kom det 33 ooo barn i 2019. «Barn må ha noen som tørker tårer og setter på plaster», sa Solberg videre (1). 9 ooo av barna som kom til Europa i fjor, kom alene eller hadde blitt skilt fra foreldrene underveis (3).

Det er mot dette bakteppet vi i Norge diskuterer om 50 er nok. Da leiren i Moria brant ned, var det en varslet katastrofe (4). Leiren var hverken bygget eller ment som fast bolig for de 13 ooo menneskene som oppholdt seg der, og fasilitetene var på ingen måte egnet for å kunne håndtere en pandemi. Da det kom et utbrudd med covid-19, ble hele leiren satt i karantene. Leger uten grenser slo alarm om at massekarantene var en farlig strategi, og de fikk rett (5). Kort tid etter sto leiren i brann, og desperate mennesker mistet det siste de hadde. Noen tar til orde for å hjelpe flyktningene der de er. Det koster minst, både $\emptyset$ konomisk og politisk, i hvert fall på kort sikt. Men å holde folk i leirer på ubestemt tid fratar dem muligheten for et fullverdig liv ( $\underline{6})$. Bevegelsesfrihet er en grunnleggende menneskerett. Hos barn som har vært innesperret, ser man angst, psykiske lidelser, 
utviklingsforstyrrelser og dårligere fysisk helse (7.). Å la folk bruke årevis på flukt, i leire og i mottak er forferdelig for dem det gjelder, men det er også uhensiktsmessig fra et utviklingsmessig og økonomisk ståsted ( $\underline{8})$.

Den viktigste årsaken til at folk flykter, er vold eller trusler om vold (모). Beslutningen om å forlate alt man eier og alt som er kjent, tas i en presset situasjon og med ufullstendig informasjon. «Til alle tider har foreldre sett på sitt nyfødte barn og spurt seg: Hvilken fremtid venter deg?», sa Solberg. Når flukt fremstår som den tryggeste løsningen, sier det noe om hva de flykter fra.

\section{«'En god barndom varer livet ut', sa Solberg. En traumatisk barndom} varer enda lenger»

Barn på flukt er spesielt sårbare for misbruk, for vold og for å bli solgt til slaveri og prostitusjon. Dette kommer på toppen av den betydelige risikoen for traumer, sykdom, skade og død som gjelder alle flyktninger. «En god barndom varer livet ut», sa Solberg (11). En traumatisk barndom varer enda lenger, den gir blant annet epigenetiske endringer $i$ DNA (9.), endringer som kanskje kan forklare noe av den økte risikoen for både psykisk og fysisk sykdom (10 $)$. Barn som er uten sine nærmeste omsorgspersoner, er spesielt sårbare. Vi kan ikke somle med å evakuere barna fra Moria. Å behandle flyktninger inhumant er ikke en akseptabel metode for å bremse migrasjonsstrømmer.

Det forplikter å være blant verdens rikeste land. Og skal man være et foregangsland når det kommer til fred og konfliktløsning, må man hjelpe når man kan. Verdier er ikke hva man sier, det er hva man gjør. Legeforeningen har, for andre gang, skrevet til utenriksministeren at «Norge bør vise internasjonalt lederskap også i den ekstraordinære situasjonen pandemien utgjør» (11). Det er en god formulering. Internasjonalt lederskap er å sette standarden for andre. For hvis ikke vi kan hjelpe, hvordan skal vi kunne forvente at andre skal?

\section{"Vi kan ikke somle med å evakuere barna fra Moria»}

I Europa er det høst, og nettene er kalde. Flyktningbarna på Lesvos har ingenting, ikke engang tak over hodet. Har de fremdeles håp? Noen av dem er alene. «Det er barna som skal føre vårt samfunn videre», avsluttet Solberg på årets siste dag og ønsket godt nyttår (1).

Bordet sto dekket med skinnende hvit duk og fint porselen, og en stekt gås sto og dampet så deilig, fylt med svisker og epler. [...] Men i kroken ved huset satt den lille piken og var død da den kalde morgenen kom, hun var frosset $i$ hjel den siste kvelden $i$ det gamle året. (12)

\section{LITTERATUR}

1. - Lag flere barn, ber statsministeren i sin nyttårstale. NRK 1.1.2019.

https://www.nrk.no/norge/statsministeren-bekymret-over-lave-fodselstall-1.14362212 Lest 16.9.2020.

2. UNHCR. Figures at a glance. https://www.unhcr.org/figures-at-a-glance.html Lest 16.9.2020.

3. Unicef. Latest statistics and graphics on refugee and migrant children.

https://www.unicef.org/eca/emergencies/latest-statistics-and-graphics-refugee-and-migrant-children Lest 16.9.2020.

4. Iacobucci G. Covid-19: Doctors warn of humanitarian catastrophe at Europe's largest refugee camp. BM] 2020; 368: m1097. [PubMed][CrossRef]

5. Leger uten grenser. Korona påvist i Moria-leiren:13.0oo mennesker tvinges til helsefarlig karantene. https://legerutengrenser.no/nyheter/korona-pavist-i-moria-leiren-helsefarlig-karantene Lest 16.9.2020.

6. van Tulleken A. Refugee crisis presents a humanitarian paradox. BMJ 2016;355: i5412. [PubMed] [CrossRef] 
7. Mares S. Mental health consequences of detaining children and families who seek asylum: a scoping review. Eur Child Adolesc Psychiatry 2020; 29. doi: 10.1007/s00787-020-01629-x. [PubMed] [CrossRef]

8. Forcibly displaced: Toward a development approach supporting refugees, the internally displaced, and their hosts. Washington, DC: International Bank for Reconstruction and Development / The World Bank, 2017.

https://openknowledge.worldbank.org/bitstream/handle/10986/25016/9781464809385.pdf? sequence $=11$ \&isAllowed=y Lest 16.9.2020.

9. Jiang S, Postovit L, Cattaneo A et al. Epigenetic modifications in stress response genes associated with childhood trauma. Front Psychiatry 2019; 10: 808. [PubMed][CrossRef]

10. Felitti VJ, Anda RF, Nordenberg D et al. Relationship of childhood abuse and household dysfunction to many of the leading causes of death in adults. The Adverse Childhood Experiences (ACE) Study. Am J Prev Med 1998; 14: 245-58. [PubMed][CrossRef]

11. Hermansen M, Christiansen MH. Flyktningene i Moria-leiren. Oslo: Den norske legeforening, 2020.

https://www.legeforeningen.no/contentassets/bd8675d39oee4487be417ob2fceo6cd4/flyktningene-imoria-leiren.pdf Lest 16.9.2020.

12. Andersen HC. Den lille Pige med Svovlstikkerne. Nasjonal digital læringsarena. https://ndla.no/nb/subjects/subject:19/topic:1:186579/topic:1:195996/resource:1:7863 Lest 16.9.2020.

Publisert: 17. september 2020. Tidsskr Nor Legeforen. DOI: 10.4045/tidsskr.20.0738

(C) Tidsskrift for Den norske legeforening 2023. Lastet ned fra tidsskriftet.no 26. april 2023. 